\title{
Prospects and Implications of Students Politics in Educational Institutions of Pakistan
}

\author{
Hashmat Ullah Khan ${ }^{* 1} \&$ Shamsuz Zaman ${ }^{1-2}$
}

1. School of International and Public Affairs, Jilin University, Changchun, Jilin, China.

2. Department of Journalism and Media Studies, Jahangirnagar University, Bangladesh.

\begin{abstract}
The objective of this study is to critically analyse the problems of students politics in the educational institutions and know about its prospects and implications. This is an important phenomenon playing crucial role in a democratic states like Pakistan. Students politics is an important research problem. There are many underlying questions like what is the importance and prospects of student politics? What are its implications? Why it leads to violence how it can be overcome and more result oriented? Students are the leaders of tomorrow therefore student politics in educational institution of a democratic state like Pakistan is very important phenomenon. It has many prospects like most of the mainstream top seed politicians are the product of student politics, providing educated and well-trained political leaders and workers, strengthen political participation, increase turnout, helpful to address the issues of students and create sense of political awareness, but at the same time it has also many implications like student unions are working as pressure groups, organize strikes, marches, using force against opponent groups, wasting student's precious time in off-campus activities, intoxication and developed weapon culture. This research is a qualitative in nature and based on critical discourse analysis, descriptive and analytical approaches.
\end{abstract}

Keywords: Educational Institutions, Students Union, Student Politics, Political Parties, Democracy in Pakistan.

\section{Introduction}

The word politics has been derived from a Greek word "polis" means the state or community as a whole (Sarfaraz et al., 2012). According to Plato, "politics" means the practice of various strategies and techniques to form a better society as compare to the existing one (Aristotle, 1996). In other words, "politics" is the procedure whereby a group of human beings makes united decisions. It is detected in all human associations, including general masses, students, academician, business and religious organizations. It helps to defend human rights, freedom of expression, thought and action, justice for all and working to attain economic prosperity to make improved living standard of all inhabitants and defend them against any threat to their assets and lives. Politics exists because of wide range of ideas, thoughts and opinions among different sections of society in which students are also included. In the politics, final decision depends on the quantity of manpower that one or more groups hold. It works as a dais for the progress of state and society as well as the development of political system. As concerned to the student, politics and concept of student power emerged in Europe in $20^{\text {th }}$ century (Luescher 
et al., 2016). Like other democratic countries, students' politics also exists in Pakistan. The main question is that why students are doing politics and what are its benefits and prospects? It is a very important issue to be discussed and to address its prospects and challenges as now a days it has assumed the shape of power politics in Pakistan affecting the schooling activities of students and deteriorating the peaceful environment of educational institutions which is a pre-requisite for study. It has extended its role and established the importance of the students in the political development through different methods i.e. energetic part in political setup, role as a pressure group, diffusion into political process and influence on policy making. Since the first phase of parliamentary history of Pakistan, students are playing very significant role in the political development of the country (Hussain, 2007). Political parties always tried to influence the student politics to exploit their potential, which creates challenges.

Some well-known objectives of the student unions are quality education, secure students' rights, leadership development, promote peaceful environment in educational institutions and political training, but if we observe the present situation, student unions have deteriorated all these primary objectives. It disturbed the students' education and relations among students belonging to opposing unions. Political parties of Pakistan founded its sub-organizations for students and always tried their best to bring students under their control and influence. The main objective of every political party behind its interest in the student politics is to get educated leadership and utilize it as a Pressure Group at the time of need (Hussain, 2012).

The politics of students in educational institutions remain very important problem in each democratic state. Faith in political organizations is very significant for the political solidity and political transformation in any state and society. Student's groups strengthen further the faith in political organizations when they experience constructive relationship in educational institutions (Ziemes et al., 2020). According to Ahmad (2020) the political pattern of the educational institutions and political socialization of students are very important signs of political involvement. The existence of politics in educational institutions is inspiring students to engage in campus politics. Political unions engage students in different political activities like study circles, agitation, protests, campaigns etc. Such activities are the sources of political knowledge, information and solid predictors of political engagement. But is has also many problem. Weak analytical capacities of civic experience of students are creating many problem in this regard. Educational institutions are the nurseries of future political leaders and workers. Student politics has very important role in the democratization, strengthening of democratic institutions and advancing of political participation. There are many underlying questions. What is the importance of student politics in Pakistan being a democratic state? Why student politics despite of its many prospects and importance creating challenges in educational institutions and why in Pakistan it is misusing and creating violence in campuses?

The issue of student politics is very complicated phenomenon. It has many valuable prospects and at the same time also has many implications. The study of Fischer (2017) says that usually leaders are University graduates, and the major subject of their study has huge influence on their policies and on the reforms, they initiate when come to power. They are intending for enhancing competence of respective governments and departments. Ballard and Brocato, (2020) analysed that if students get proper experience in politics since student life, it will surely have positive impacts on their policies and on the reforms they initiate. Therefore, Political participation and engagement are correlated with the welfare of students in different ways. Saha and Print (2010) says that the prior participation of student in politics is a good forecaster of adult political participation because they seek politics through this way and later on that 
experience help them in national politics. The participation of students in politics and the elections in educational institutions work as a valuable and helpful experience in the training of students for upcoming life as an enthusiastic citizen. An important thing in this regard is why students are going to engage in politics? According to Koiv (2011) generally, students facing problems regardless of the kind of issue, evaluating more strong protest as a factor of their upcoming political involvement while those which are without issues emphasize further rights and volunteer works. Those students facing more problems are participating more actively in protests. Those students who participate in volunteer events are more prone to engage in politics when they grow up. Political obligation is an important feature of students thoughts regarding the upcoming active person in terms of involvement in politics and those having no problematic behaviour are proved more positive and constructive than those having problematic behaviour in future political engagement. Generally, students are also taking active participation in community services (Niemi et al., 2000). The study of Wa and Bao (2013) says that in countries like China students more actively participate in political engagement in Universities aimed to attain leadership. The Chinese Communist Party membership is an important factor influencing the political behaviour and political participation of students. It is making students more advantageous in getting leadership position as compare to other.

At present social media has also proved to be of great influence on the student politics, making their opinion and bringing political awareness among them. Social media is not only channel of information but playing an important role in communication of ideas, emotions and feelings. In Pakistan social media played a very important role in creating political awareness among students and their active role in politics. The using of social media is contributing to political awareness, which positively impact the political and civic participation. Political influences also moderate the effects of social media usage on political engagement (Gan et al., 2017). Political interaction in society through social media is associated to constructive impacts on society and politics. But Bailey and Williams, (2016) says that the main problem is that as students are yet not get fully matured and have not vast experience therefore there are some contradictions happen between their perceived and actual political ideology. Larger perceived conservatism correlates to perform more strategies that are liberal.

\section{Background of Students Politics in Pakistan}

Student unions are present in universities and colleges since British era and taking active part in politics. In British India, the appearance of youth as a new political class and its active participation was became possible by the rapid development of educational system and political awareness (Rudolph et al., 1971). Student also took active part in Pakistan's independence movement. The Muslim Students Federation (MSF) was established before the independence of Pakistan, played a dynamic and very active role in Pakistan movement in close connotation with Muslim League. Soon after independence the "Islami Jamiat Talaba" (IJT) was founded on December 23, 1947 at Lahore in the presence of Maulana Abul Ala Maudodi, the then president of Jumat-e-Islami, and Democratic Students Federation (DSF) was established by the Communist party of Pakistan in 1984 at Gordon College Rawalpindi (PILDAT, 2008). The Democratic Students Federation later on amalgamated itself into a wider platform called "All Pakistan Students Organization" (APSO) (PILDAT, 2008). In the beginning, student unions were mostly the organizations of progressive, broadminded and leftists, and addressing of students' problems were its main concentration. Students politics was more ideal, played an important role. Political parties were impressed from their success and strength, therefore they started to promote student politics in educational institutions. 
Soon after independence, political situation of Pakistan faced a lot of calamity, which also transformed the direction, and nature of student politics. Another most important development in this respect, which brought students to mainstream, was the Martial law imposed in 1958. The political parties had neither street power nor funds to face the problem of Martial Law. They had not the ability to confront the military regime (Hasan, 1996). In those circumstances' students came forward against the General Ayub Khan Martial Law regime (Hasan, 1996). Moreover, student movements against General Ayub Khan's education policy in 1961 and 1962, three years degree course and University Ordinance 1963 were some provoking matters of students' agitation (Ahmad, 2000), which brought them into main stream politics.

The history of student unions in Pakistan has many ups and downs. General Zia-ul-Haq imposed ban on student unions in 1984. He believed the agitations of students as a potential threat to his illegal martial law regime. Through the Martial Law Order No. 1371 student unions were banded on February 9, 1984. Likewise, Martial Law Order No. 227 issued by Sindh Martial Law Administrator banded student federations on February 11, 1984. Though many efforts were made to lift the ban but could not succeed until 1988. Ultimately, when Benazir Bhutto was elected as the Prime Minister of Pakistan, in her opening speech to the Assembly on December 02, 1988, she lifted the ban. Again, on July 1, 1992, Supreme Court through an order imposed ban on student's unions. After long time when Pakistan People Party once again win elections in 2008 then the PPP Prime Minister Yousaf Raza Gilani announced the restoration of student federations in his first address to the assembly on March 29, 2008 (Ali et al., 2008). Though, it was announced but student unions could not be restored till today.

\section{Research Methodology}

This is a qualitative study in nature and based on critical discourse analysis. Critical discourse analysis is multi disciplinarily and an interpretation of complex associations between writing, conversation, societal view, power, people and cultures (Wodak \& Meyer, 2001). It is developed in 1990s by a group of professors such as Theo van Leeuwen, Gunther Kress, Teun van Dijk, and Norman Fairclough to examine social issues (Amoussou \& Allagbe, 2018). This technique has many basic principles including focus on relations of power in a group, issue oriented, uncovering hidden implicit things, which influence human beliefs, social influence, and solidarity with dominated group and study relation between a discourse and society.

The descriptive approach is also adopted in this study which focus on how, where, what and when questions are trying to answer. A research method is using in a wide variety of social research to examine any single or more variables, but not Like in experimental studies, the investigator doesn't manipulate or control the variable, but only observes and measures the variable. This descriptive method in Social Sciences research is focused at making thorough observations, comprehensive documentation and analysis of the problem. These steps necessarily based on scientific techniques including precise and replicable. Therefore, a study based on this method is more reliable than that based on casual observations method.

In the discussion, analysis of different dimensions related to student politics and concluding the whole phenomenon the analytical approach is also adopted. Required data, facts and figures to support the arguments are collected from secondary sources including research papers, books, reports, online sources and newspapers. 


\section{Prospects of Students Politics}

Today students' politics is an important concept of Political Science because after political parties, it is the most influential and important political association (Wagoner, 1972). Pakistan has a long history of student politics having many prospects and positive impacts on the political development of Pakistan. Jinnah's perception about the role of students in future was that: "students are the nation's builders of the coming days; therefore, they should well equip their selves by education, discipline and training for the difficult tasks lying ahead. They should realize and understand the greatness of their responsibilities and duties and should be ready to bear it" (Afzal, 1980). The most important prospect of student unions and their politics for democracy is that it provides competent and well-trained leadership from middle and lower middle class, which probably strengthens democracy. It is also playing main role in determining the directions of politics in Pakistan as most of the mainstream politicians are exstudents leaders.

Sarfaraz et al. (2012) recorded that nearly $84 \%$ of youth (age 18-29) in Pakistan have found to think that politics can bring positive change in the state and society. Also $80 \%$ of youth are ready to play their part in politics. As Pakistan has 63 per cent population under the age of twenty-five it can prove a deep demographic modification with wide ranging political and socio-economic effects. To advance the quality of engagement with Colleges and Universities students could have important impact on politics and democracy in Pakistan (Rehman \& Naqvi, 2013). The youth taking part in Politics leads to political development of the state and society and also enables them to struggle for their rights and privileges. It also provides a legitimize forum to bring about a desired change and modification in the country.

Students' involvement in politics advances their political consciousness and experience teaching them how to engage in a democratic state and society. In developed countries, students conceive it as their responsibility to play their due role in the politics of their country. This thing strengthens democracy and democratic institutions. In Pakistan, students have little opportunity to take part in politics and that's why they have lack of political consciousness and awareness that inspire their approach and attitude towards democracy and democratic course. They are the leaders and a solid force of tomorrow that should have political awareness and should have sound political knowledge. Political Consciousness is supposed to be important and obliging for right democracy because with the help of political consciousness, political leadership and politicians can be made responsible and accountable (Ahmad et al., 2015). They have the potential to bring political consensus and awareness among illiterate citizens of their respective areas if they are properly trained in student unions of educational institutions. Thus, the role of students becomes more important in the whole political development of Pakistan.

A glance on the literature of political history of Pakistan indicates that student federations have also played dynamic and a very active function in numerous national political movements either related to it or not. Their movement against West Pakistan University Ordinance of 1962 compelled the authoritarian military regime of General Ayub Khan to revise the ordinance. They had also organized a very strong movement against the Tashkent Declaration, which gradually changed to a solid nationwide movement ultimately compelled Gen. Ayub Khan to resign in 1969 (Ali et al., 2008). Another strong campaign of student unions was against the decision of Zulfiqar Ali Bhutto's government to recognize Bangladesh. The 1970's campaign of Pakistan National Alliance to overthrow Zulfiqar Ali Bhutto government also involved a huge number of students. Undoubtedly, Bhutto's era witnessed the highest activism of students 
in politics (Ali et al., 2008). Its voice is not always limited to national issues but on many occasions, it has also raised voice about international issues.

In Pakistan, students' organizations have also played a remarkable role in political mobilization. It continuously provides dynamic political leadership to Pakistan, which strengthens political institutions and democracy. The Universities and Colleges of Pakistan are also serving as the nurseries for the development and promotion of political thought and awareness. Therefore, shying away of students from politics in Pakistan is not good. Student unions are very substantial and effective groups strengthening any movement in which they participate (Hussain, 2012). Students' consensuses and awareness which they obtain while doing politics in educational institutions probably lead to emergences of competitive leadership capable to put the state on right track, but unfortunately, today nepotism, favouritism, political downfall, corruption, bribery and defilement of fundamental rights of the general public are due to the solid grip of feudalism and elite class in the nation's politics. Student politics gave birth to leaders from middle and lower middle class. Involvement of middle class and lover middle class citizens in politics will put the state on the right path of development. It will also make the electoral process fair and transparent. Thus, these real representatives of citizens will protect their rights (Ali et al., 2008). Student politics is playing very important role in democratization and strengthen of democratic institutions in all democratic countries. It is providing competitive and well-trained leaders and political workers to political parties. It ensures political participations and political awareness, provides students a platform to rise voice for their due rights and necessary to stimulate the democratic culture in Pakistan. It is also playing very decisive role in raising awareness and understanding about how democratic system works in Pakistan. In its absence, the country would definitely face many challenges in this regard. Democratic norms are static in Pakistan since the ban of student politics.

Students are the future of the nation. Student of today is the leader of tomorrow and educational institutions are the nurseries of the future leaders. In Pakistan, students of today are more skilled and educated than the students of the past. Therefore, their active contribution into politics would prove to be beneficial. Politics is the skill, ability and knowledge how power is exercised. It aimed to manage the affairs of people through public power. It is an essential element of the business and affairs of education. Politics in educational institutions is not only aimed to elect the campus board members or other student's representative but it is an essential element of daily life. The Student's councils and unions are not only leading to a productive voice of students but it is also an instrument of shaping the minds of youth for democratization and bringing change in state and society through the power of vote rather than through violent means. Such unions of students can be a means of active involvement of young citizens in healthy activity for the benefits of state and society in any democratic state like Pakistan. Though, falling in the power politics of ethnic and religious politics doing by some parties in the country creating problems. Likewise, because of the interference of professional politicians in the student's campus politics also lead to violence and deteriorating the advantages of student politics. Students need to enter politics when they have sufficient experience and knowledge about such specific arena of power politics. The early stage students when they start participation in politics, they are more likely to stay in politics during their whole life and thus enlighten the upcoming generation progressively. Some people are of the opinion that it is better for students that they should first complete education, develop career and make adequate bank balance then go to participate in politics. However, this idea is not good because they would have lack of proper political training, enthusiasm and lack of interests in politics. Such politicians will do politics only for personal interest and increasing Bank balance, not for the 
services of community. There are many benefits when students enter politics in their early stage because the students of today are well learnt and full of enthusiasm and energy. It will make them well trained and devoted politician of the future. Their participation is stimulating the entire arena of politics of the state. It is very helpful in forming the destiny of state full of proficiency. Though in Pakistan on many occasions it is observed the student politics created violence and strain situation in educational institutions. This is not the fault of student politics but the interference of political parties, ethnic and religious groups from outside and their power politics to use students for their vested interests.

At present young people of Pakistan are civic oriented than before therefore unions can provide them healthy opportunities and good working environment. There are a lot of opportunities in student politics for students to become good and skilled leaders able to assume responsibilities and perform this duty even in later life. The elected members of students are their representatives. They are also in charge of arranging and sponsoring diverse type of services and programs related to students benefits, celebrations etc. As mentioned earlier students of today are the leaders tomorrow of every state. Therefore, it is necessary for them to know about and get aware the politics of the country. Before taking part in the politics of the country, they must seek more and more about politics, heroes, national interests, administrative skills, leadership qualities, courage of sacrifice, community works and running of public offices and government. There are also many other advantages of student politics in any country. It creates political mobilization in society because young people composed a huge portion of population of the country and thus turnout of votes in election significantly increase which is very healthy for strengthen of democracy and democratization. On the other hand, if young people do not go to cast their votes then it will lead to political apathy in the country as well as their voice will not be heard. It also helps students to get aware about their due rights and the meaning of vote and the right use of vote. At present people of Pakistan mainly casting votes based on the developmental works done by the respective candidates like roads, street etc. It can also control the practice of horse-trading in election, which made the politics very dirty in Pakistan. A talented student is supposed to be good doctor and engineer; it can be good politician too and serve Pakistan very well even more than a doctor and engineer. Only an anti-democratic regime can refuse the student politics. It is very bad to ban doing politics and ban unions and ban on political discussion with fellows in the educational institution of a democratic country.

\section{Implications of Students Politics}

Apart from prospects, the student politics in educational institutions of Pakistan have many challenges and implications. Most importantly, student unions are observed to work as a pressure group. They pressurize the administration of their educational institutions to surrender to their demands, which disturb the environment of educational institutions. Though students themselves, neither contest election nor put forward any program but they have very important role in the elections and the programs put forward by political parties as most of the time they are working as pressure groups for their concerned parties, which is not a healthy activity. In Pakistan, the opposition political parties through its affiliated student organizations pressurize government. Students apply different approaches and methods in order to influence the situation and advance their interests. In order to attain their aims and objectives the method, which they frequently use, is "strike" (Hussain, 2012). They use both direct and indirect methods. Among the direct methods, strikes, marches, mass rallies and protests are very effective techniques. Sometimes they also use indirect approaches like lobbying in order to fulfil their objectives. 
Every political party of Pakistan is struggling to engage with students and exploit their potentials. As student unions are associated with political parties, therefore some parties mislead them and use them to fight their proxy war against their opponent political parties. Therefore, educational institutions have become the battlefield of political parties' proxy wars. Another implication of student politics is the drug culture mostly found among those students associated with unions and student politics. Most members of the student unions are drug addicts. Weapons culture is also brought to universities and colleges by student federations. Above all doing politics probably waste a lot of their time, energy and resources. If they utilize their time and potential in studies, which they are, using in politics, then can achieve Excellency in learning and education a lot. Universities and colleges are deemed the nurseries of new idea and a place where friendly and fruitful discussions are important to be done, but the student politics brought the useless topics of discussion and debates like political elites.

The above-mentioned activities of student unions lead to apathy among Pakistani students towards politics. Its causes are non-existence of true politicians and leaders, corrupt electoral system, feudalism, lack of consciousness about politics, corrupt bureaucracy, flouting public interests, pre-poll rigging and lack of fundamental rights (Sarfaraz et al., 2012). Political apathy indirectly leads to the crisis of leadership growth because limited number of people turnout to cast their votes and take part in politics permitting un-true leaders to be elected thus helping the corrupt and immoral political structure.

The time and life of students are very valuable, and this time is the critical stage of their lives, which determines their destiny. Therefore, critics of student politics oppose it on the ground that any other activities like participation in politics during the age of study waste their precious time lead to destroy their studies. They say that study is more important for students than politics. Once this phase of study passes then it will not come back. Another aspect of student politics is that they get engaged in numerous off-campus events, which negatively influence their schooling activities and results. The participation of students in political activities is affecting their studies and wasting their precious time and resources. In Pakistan, in educational institution student politics also created intimidation, violence, intoxication, weapons culture and pressure groups, which made the educational institutions gradually dangerous and created unhealthy study environment. It is common practice among the leaders of student to stay year after year in the institutes and earn many degrees. Mostly the leaders also have long criminal records and involved in unlawful activities and violence against opponents. Violent clashes among groups of students are very common in every institute and even many students lost their lives in the clashes. Many materialist people view the student politics as source of power and steppingstone to national politics. Likewise, associations, unions, political discussions, distribution of materials related to their groups and political meetings inside the campuses creating always disorder and tussles among students. Student unions are also financed by the political parties of their affiliation therefore the parties are also exploiting them for their interests and getting their services during general elections. Many political parties also giving tacit support to their affiliated student to indulge in extortion. Political parties are also using the educational institution to recruit new party members. Such things destroyed the essence of student politics in Pakistan.

\section{Conclusion}

In Pakistan, like other democratic countries student politics in educational institutions plays an important role in the political participation, strengthening democratic norms, national politics 
and political development. It is providing good political leaders and political workers and creating sense of responsibility in students. Since independence, it has provided a lot of talented leaders that strengthen democracy and democratic institutions in Pakistan. However, due to power politics among political parties' students are used as proxies in political clashes, which have brought violence to educational institutions. Apart from being working as a pressure groups and having many other negative aspects student politics have many positive impacts and prospects. The most important prospect of student politics is to provide competent and well-trained leadership from middle and lower middle classes, which is probably strengthening democracy and democratic norms in institutions. Student's unions are also playing a remarkable role in political mobilization. The universities and colleges of Pakistan are serving as the nurseries for the development and promotion of political thoughts and political awareness. Shying away of students from politics in Pakistan is not good. It will lead to collapse of the political system of the state, ultimately affecting the lives of everyone.

\subsection{Recommendations}

- Pakistan has been badly de-politicized. It is the need of the hour to restore student unions to get educated, well trained and hardworking political leadership and political workers.

- Rules and regulations for student unions and code of conduct for student politics are essential. It will probably eradicate militancy, violence, tendency of pressure groups, drugs culture and other evils existing among student unions.

- If political parties of Pakistan offer fresh ideas, energy and enthusiasm, they may benefit from students politics and it may probably lead to end political apathy among students.

\section{References}

Afzal, R. (1980). Selected Speeches and Statements of the Quaid-i-Azam Mohammad Ali Jinnah (1911-34 \& 1947-48). Darus Shaoor.

Ahmad, A. (2020). Politics on Campus: Why do Students Join Campus Politics in Islamabad? Liberal Arts and Social Sciences International Journal (LASSIJ), 4(2), 52-59. https://doi.org/10.47264/idea.lassij/4.2.5

Ahmad, A. D. (2000). Student Movements in Pakistan. [In Urdu]. Mushal.

Ahmad, Z., et al. (2015). Comparing the Level of Political Awareness Among the Students of Social and Natural Sciences: A Case Study of Public Sector Universities in Pakistan. Pakistan Journal of Life and Social Science, 13(2), 64-67.

PILDAT. (2008). Revival of Students Unions in Pakistan. Pakistan Institute of Legislative Development and Transparency. http://youthparliament.pk/uploads/public/7fecfdd358b122494727d641841f5cc7.pdf

Amoussou, F. \& Allagbe, A. A. (2018). Principles, Theories and Approaches to Critical Discourse Analysis. International Journal on Studies in English Language and Literature (IJSELL), 6(1), 11-18.

Aristotle. (1996). Aristotle: The Politics and the Constitution of Athens. Cambridge University Press. $\quad$ https://www.cambridge.org/pk/academic/subjects/politics-internationalrelations/texts-political-thought/aristotle-politics-and-constitutionathens?format $=$ PB\&isbn $=9780521484008$

Bailey M. \& Williams, L. R. (2016). Are college students really liberal? An exploration of student political ideology and attitudes toward policies impacting minorities. The Social Science Journal, 53(3), 309-317. 
Ballard, Ni \& Brocato, (2020). Political engagement and wellbeing among college students. Journal of Applied Developmental Psychology, 71, 101-109. https://doi.org/10.1016/j.appdev.2020.101209

Fischer, M. (2017). Support for free-market policies and reforms: Does the field of study influence students' political attitudes? European Journal of Political Economy, 48. 180-197.

Gan, C., Lee, F., \& Li, Y. (2017). Social media use, political affect, and participation among university students in urban China. Telematics and Informatics, 34(7), 936-947.

Hasan, M. (1996). Public and Politics in Pakistan. [Urdu]. Sarang Publication.

Hussain, M. (2012). Students as the Pressure Group in Pakistan's Politics 1947-1958. Pakistan Journal of History and Culture, XXXIII (1), 157-172.

Hussain. (2007). Over 70 percent Pakistani youth indifferent to politics. http://www.nowpublic.com/politics/over-70-cent-pakistani-youth-indifferentpolitics

Koiv, K. (2011). Attitudes towards future political participation among students with and without behavioural problems. Procedia - Social and Behavioural Sciences, 29, 15181523.

Luescher, T. M., Klemencic, M and Jowi, J. O. (2016). Student Politics in Africa: Representation and Activism. Cape African Minds.

Niemi, R. G., Hepburn, M. A., \& Chapman, C. (2000) Community Service by High School Students. Political Behaviour, 22(1), 45-60.

Rehman, S., \& Naqvi, A. (2013). A Political or Depoliticized? Pakistan's Youth and Politics. Jinnah Institute.

Rudolph, L. I., Rudolph, S. H. \& Ahmed, K. (1971). Student Politics and national Political in India. Economic and Political Weekly, 6(30), 1655-1668.

Saha, L. \& Print, M. (2010). Student school elections and political engagement: A cradle of democracy? International Journal of Educational Research, 49(1), 22-32.

Sarfaraz, A., et al. (2012). Reasons for Political Interest and Apathy among University Students: A Qualitative Study. Pakistan Journal of Social and Clinical Psychology, 10(1), 61-67.

Wa, C. L. \& Bao, W. (2013). The effects of individual characteristics, socioeconomic status, and political engagement on the attainment of student leadership roles in Chinese University students. International Journal of Educational Development, International Journal of Educational Development, 33. 149-155.

Wagoner, R. (1972). Party Politics and Pressure Groups. Thomas and Nelson.

Wodak, R \& Meyer, M. (2001). Methods of Critical Discourse Analysis. SAGE.

Ziemes, J. F., Laudenberg, K. H. \& Abs, H. J. (2020). The impact of schooling on trust in political institutions: differences arising from students' immigration backgrounds. Learning, Culture and Social Interaction, 26. https://doi.org/10.1016/j.lcsi.2020.100429 